\title{
Effects of Different Levels of Sunflower Oil in Diets on Growth Rate, Carcass Traits and Meat Composition Relationship in Growing Rabbit
}

\author{
Rosalie BĂLĂCEANU (DOJANĂ) ${ }^{1}$, Gabriel COTOR ${ }^{1}$, Iuliana CODREANU², Mara GEORGESCU ${ }^{3}$, \\ Nicolae DOJANA ${ }^{2}$ \\ ${ }^{1}$ Department of Physiopathology, ${ }^{2}$ Department of Physiology, ${ }^{3}$ Department of Food Safety and Hygiene, \\ Faculty of Veterinary Medicine, U.S.A.M.V.-Bucharest, Mărăști Street, 59, 050097, Bucharest, Romania \\ rosalie_timeea@yahoo.com
}

Bulletin UASVM Veterinary Medicine 71(2) / 2014,

Print ISSN 1843-5270; Electronic ISSN 1843-5378

DOI:10.15835/buasvmcn-vm: 10224

\begin{abstract}
The researches were performed on three growing ( 14 weeks aged) rabbit groups fed by different levels of vegetal (sunflower) oil enriched diets: two experimental groups (5 capita each) were fed by $5.5 \%$ and $6.6 \%$, respectively, sun flower oil supplemented diets, vs. $2.4 \%$ vegetal oil content in a control group diet. The experimental feeding lasted 28 days. Before and at the end of the experimental feeding period the rabbits were weighted and the weight gain was calculated. At the end of the experimental feeding period the rabbits were slaughtered. Then, carcasses were analyzed for dressing percentage, dissectible fat, meat/bone ratio and meat $p \mathrm{H}$ evolution from slaughter to the nest 24 hours. The meat was analyzed for its composition: fat, protein, dry matter and ash. The resulted showed that feeding for three weeks of the young rabbit led to an increase of the weight gain $(\mathrm{P}=0.0353)$, seeming to be proportional to the supplement level. Dressing percentage and meat/bone ratio showed an improvement in the supplemented rabbits. Dissectible fat of carcass was found significantly higher in supplemented rabbits vs. control $(\mathrm{P}=0.0226)$. Fat content and dry matter of the meat were found also higher in experimental treated groups vs. control $(\mathrm{P}=0.03231$ and $\mathrm{P}=0.0454$, respectively), while protein was found in lower percentage. Ultimate $\mathrm{pH}$ was found lower in experimental groups and some sensory traits of the meat were found improved. In conclusion, feeding the growing rabbits by different sunflower oil enriched diets could improve growth rate, carcass traits and some meat sensory traits, due to an increase of carcass dissectible fat and an increase of meat fat content.
\end{abstract}

Keywords: vegetal oil enriched diets, carcass traits, meat composition, rabbits.

\section{INRODUCTION}

Getting rabbits with a higher dressing percentage, a higher meat / bone ratio or a decrease of the dissectible fat percentage of the carcass could be the permanent objectives of the most the rabbit producers. Rabbit meat is highly valued for its nutritional and dietary properties; it is a lean meat with a low-fat content and less saturated fatty acids and cholesterol than other meats (Dalle Zotte, 2004). On the other hand, the nutritional role of meat is controversial because consumers generally consider that high ingestion of meat contributes to excess fat, cholesterol and saturated fatty acids, which are strongly linked to obesity and cardiovascular problems (Hernández, 2008). Different strategies can be followed to increase beneficial meat components in order to obtain healthier rabbit meat (Hernández, 2008). Efforts to decrease production costs must be considered in comparison with the degree of change in the carcass traits and meat composition. Thus, supplementing diets on fats (cheaper) could improve carcass traits but it should be considered taking into account the consumer demands. According to the submitted, the present work aims to research the effects of different levels of sunflower oil in the rabbit diets on the main carcass traits and meat composition of the rabbits.

\section{MATERIAL AND METHODS}

The researches were performed on growing (11 weeks aged) Supercuni rabbit groups. A control group ( 6 capita) was fed by a standard diet. The standard diet was based on dehydrated lucerne, 
wheat middling, barley, sugar-beet pulp, soya-bean meal, sunflower oil, DL-metionine and a mineralvitamin premix. Afferent calculated chemical composition of standard diet was as it follows: 910 $\mathrm{g} / \mathrm{kg}$ dry matter (DM), crude protein $166 \mathrm{~g} / \mathrm{kg} \mathrm{DM}$, crude fiber $186 \mathrm{~g} / \mathrm{kg}$, ash $78 \mathrm{~g} / \mathrm{kg} \mathrm{DM}$, gross energy $17.6 \mathrm{MJ} / \mathrm{kg}$ DM and fat (sunflower oil) $24 \mathrm{~g} / \mathrm{kg} \mathrm{DM}$ of diet. Two experimental groups (5 capita each) were fed by two different levels of vegetal (sunflower) oil enriched diets: group A - $55 \mathrm{~g}$ fat/kg DM and group B - $66 \mathrm{~g}$ fat/kg DM, respectively, vs. $24 \mathrm{~g} / \mathrm{kg}$ DM in control. The experimental feeding lasted 28 days. Before and at the end of the experimental feeding period the rabbits were weighted and the weight gain was calculated. At the end of the experimental feeding period the rabbits were slaughtered in a slaughter house. The warm carcasses (together with head, thoracic organs, liver and kidney) were analyzed from their traits point of view: dressing percentage, total (perirenal + scapular + inguinal) dissectible fat, meat/bone ratio from the hind legs, meat $p \mathrm{H}$ evolution from slaughter to the nest 24 hours, according to Blasco and Ouyahoun (1993).

The meat samples from the Longissimus dorsi muscles were analyzed for their composition: fat, protein, DM and ash. DM was determined by drying in oven at $103 \pm 2^{\circ} \mathrm{C}$. Fat content was determined by extraction with organic solvents using the Soxlet method. Ash content was determined by calcination at $550^{\circ} \mathrm{C}$ of meat samples dehydrated for 16-18 hours. Meat protein content was determined by calculating the difference between fat content, water, minerals and total muscle mass, according to standards of AOAC. Evolution of meat $\mathrm{pH}$ was monitored using a Hanna $p \mathrm{H}$ meter, in the muscle tissue of the hindquarters, from warm carcass to the ultimate $p \mathrm{H}$, at 24 hours.

Samples from Quadriceps femoris muscle were matured at $4^{\circ} \mathrm{C}$ for 3 days. Then, the samples were heated at mild boiling in water $(0.6 \% \mathrm{NaCl}$ solution) at one part muscle to two parts water until the core temperature reached $85^{\circ} \mathrm{C}$. Heat-treated meat was cooled to room temperature, sliced and evaluated. Sensory analysis included the evaluation of aroma intensity, aroma quality, tenderness, juiciness, taste intensity, taste quality and the overal senspry quality on a scale from 1 to 5 points according to Bielanski and Kowalska (2008).

The results are presented as mean \pm SE and they were statistically analyzed using ANOVA variance f-test from STATISTICA 6.0 program. The differences between mean values of experimental groups and control were considered significant when the probability (P) of the null hypothesis was less the $5 \%$ $(\mathrm{P}<0.05)$. To find the differences between each group and control, Tuckey test was performed.

\section{RESULTS AND DISCUSSION}

Table 1 shows the results regarding the effects of experimental feed on the daily weight gain and the dressing percentage. As it is shown in table 1 , the weight gain increased significantly in the experimental fed groups vs. control $(\mathrm{P}=0.0343)$. On the same subject, Saleh et al. (2013) fed young rabbits (10 weeks of age) by $2.5 \%$ linseed oil enriched diets from 4 to 10 weeks of age. Although feed intake was decreased significantly $(\mathrm{P}<0.05)$ by the dietary linseed oil and organic selenium, body weight gain was significantly $(\mathrm{P}<0.05)$ increased. But no detail is given on the different fed levels on the weight gain. Our results could suggest that the higher levels of vegetal fat in fattening rabbit diet could increase around of $66 \mathrm{~g}$ fat $/ \mathrm{kg}$ DM in diet, but no more. Similar results were reported by Bălăceanu et al. (2013) in fattening rabbits fed by linseed oil enriched diets.

Dressing percentage was also found increased in for both experimental fed groups. The results reported by other authors seem to be controversial, depending to the sort of fat, duration of the feeding, level of the fat in diet or the rabbit age. Fernández and Fraga (1996) studied the influence of dietary fat inclusion on feed intake, growth rate, feed efficiency, carcass traits, and body chemical composition in rabbits but they reported no modification of the dressing percentage according to the fat level. Xiccato (1999) reported that different levels of feed restriction proportionally reduced the dressing percentage. On the other hand, Pla and Cervera (1997) reported that vegetal fat and animal fat enriched diets led to a significant increase of dressing yield in rabbits, with a better food conversion efficiency ratio. Instead, males had higher food conversion rate and smaller dressing yield vs. female.

The result regarding the effects of sunflower enriched diets on the carcass traits are given in Table 2.

According to the data presented in Table 2, the dissectible fat was found significantly increased for all the anatomical regions from which it was collected: perirenal, periscapular and inguinal 
Tab. 1. The effects of sunflower enriched diets on weight gain, slaughter weight, hot carcass weight and dressing percentage in 11-week-age rabbits following 28 days of experimental feeding (mean $\pm \mathrm{SE}$ )

\begin{tabular}{|c|c|c|c|c|c|c|}
\hline Item & $\begin{array}{c}\text { Initial living } \\
\text { weight } \\
\text { (11 weeks old) } \\
\end{array}$ & $\begin{array}{l}\text { Final living } \\
\text { weight (15 } \\
\text { weeks old) } \\
\end{array}$ & $\begin{array}{l}\text { Weight gain } \\
\text { (g/day) }\end{array}$ & $\begin{array}{c}\text { Slaughter } \\
\text { weight }\end{array}$ & $\begin{array}{c}\text { Hot carcass } \\
\text { weight }\end{array}$ & $\begin{array}{l}\text { Dressing } \\
\text { percentage }\end{array}$ \\
\hline $\begin{array}{c}\text { Control } \\
\text { (24 g/kg DM vegetal } \\
\text { oil in diet, } \mathrm{n}=6)\end{array}$ & $\begin{array}{c}1,760.5 \pm \\
15.5\end{array}$ & $2,586.0 \pm$ & $\begin{array}{c}29.5 \pm \\
3.0\end{array}$ & $\begin{array}{c}2,505.5 \pm \\
54.5\end{array}$ & $\begin{array}{c}1,402.0 \pm \\
66.0\end{array}$ & $\begin{array}{l}56.0 \pm \\
4.4\end{array}$ \\
\hline $\begin{array}{c}\text { Group A } \\
\text { (55 g fat/kg DM } \\
\text { in diet, } n=5 \text { ) }\end{array}$ & $\begin{array}{l}1,810.0 \\
\pm 10.5\end{array}$ & $2,823.6 \pm$ & $\begin{array}{c}36.2 \pm \\
3.5\end{array}$ & $\begin{array}{c}2,780.0 \pm \\
94.0\end{array}$ & $\begin{array}{c}1,748.5 \pm \\
76.6\end{array}$ & $\begin{array}{c}62.9 \pm \\
4.8\end{array}$ \\
\hline $\begin{array}{c}\text { Group B } \\
\text { (66 g fat/kg DM } \\
\text { in diet, } n=5 \text { ) }\end{array}$ & $\begin{array}{c}1,690.0 \pm \\
22.2\end{array}$ & $2,801.6 \pm$ & $\begin{array}{l}39.7 \pm \\
4.4\end{array}$ & $\begin{array}{c}2,711.4 \pm \\
54.0\end{array}$ & $\begin{array}{c}1,708.2 \pm \\
50.5\end{array}$ & $\begin{array}{l}63.0 \pm \\
2.4\end{array}$ \\
\hline$P$ value & & & 0.0343 & & 0.0500 & 0.0430 \\
\hline
\end{tabular}

Notice:

$\mathrm{n}=$ number of animals

$\mathrm{P}$ value was calculated by ANOVA single factor for groups A and B vs. control

Tab. 2. Effect of different levels of fat enriched forages on the total dissectible fat and meat/bone ratio of the warm carcass in rabbits following 28 days of experimental feding

\begin{tabular}{cccccc}
\hline Item & $\begin{array}{c}\text { Perirenal fat } \\
(\%)\end{array}$ & $\begin{array}{c}\text { Scapular fat } \\
(\%)\end{array}$ & $\begin{array}{c}\text { Inguinal fat } \\
(\%)\end{array}$ & $\begin{array}{c}\text { Total dissec- } \\
\text { tible fat }(\%)\end{array}$ & $\begin{array}{c}\text { Meat / bone } \\
\text { ratio }\end{array}$ \\
\hline Control & $1.46 \pm$ & $0.87 \pm$ & & & $2.84 \pm$ \\
(24 g/kg DM vegetal & 0.09 & 0.12 & $0.54 \pm 0.05$ & 0.29 & $\begin{array}{c}5,12 \pm \\
1,10\end{array}$ \\
oil in diet, n=6) & $1.81 \pm$ & $1.40 \pm$ & $0.51 \pm$ & $3.72 \pm$ & $5,31 \pm$ \\
Group A & 0.59 & 0.05 & 0.11 & 0.65 & 0,98 \\
\hline (55 g fat/kg DM in diet, $\mathrm{n}=5)$ & $1.80 \pm$ & $1.52 \pm$ & $0.90 \pm$ & $4.22 \pm$ & $5,55 \pm$ \\
Group B & 0.55 & 0.12 & 0.18 & 0.32 & 1,80 \\
\hline (66 g fat/kg DM in diet, $\mathrm{n}=5)$ & 0.0303 & 0.0019 & 0.0465 & 0.0226 & 0.0298 \\
\hline P value & & & &
\end{tabular}

Notice: meat / bone ratio was measured on the hind legs.

$(\mathrm{P}<0.05$ for both the experimental fed groups vs. control). Fernández and Fraga (1996) studied the influence of diet and slaughter weight on feed intake, growth, feed efficiency, carcass characteristics, and body chemical composition in rabbits. Although the main measurements of carcass were not influenced by fat addition, the authors reported that the rabbits fed by diets containing the highest fat percentage had the highest weights of perirenal $(\mathrm{P}<0.001)$ and scapular $(\mathrm{P}<0.01)$ depots and the highest body fat content $(\mathrm{P}<0.01)$. Pla and Cervera (1997) reported differences regarding the three colour parameters of the carcass in vegetal fat enriched diet fed rabbits vs. animal fat enriched diet fed rabbits, but no data on meat/bone ratio were done. According to our findings, meat/bone ratio increased too, the increase being significantly higher for both, $55 \mathrm{~g}$ fat/kg DM in diet group and $66 \mathrm{~g}$ fat/kg DM in diet group. The increase was proportional to the fat percent content of the fodder.

The evolution of the meat $p \mathrm{H}$ measured on Longissimus dorsi during the first 24 hours from the slaughter is presented in Fig. 1.

As it can be seen from the analyzed results, $p \mathrm{H}$ values 20 to 30 minutes after cutting showed no significant differences from control. Instead, the final $p \mathrm{H}$ values decreased proportionally with increasing 


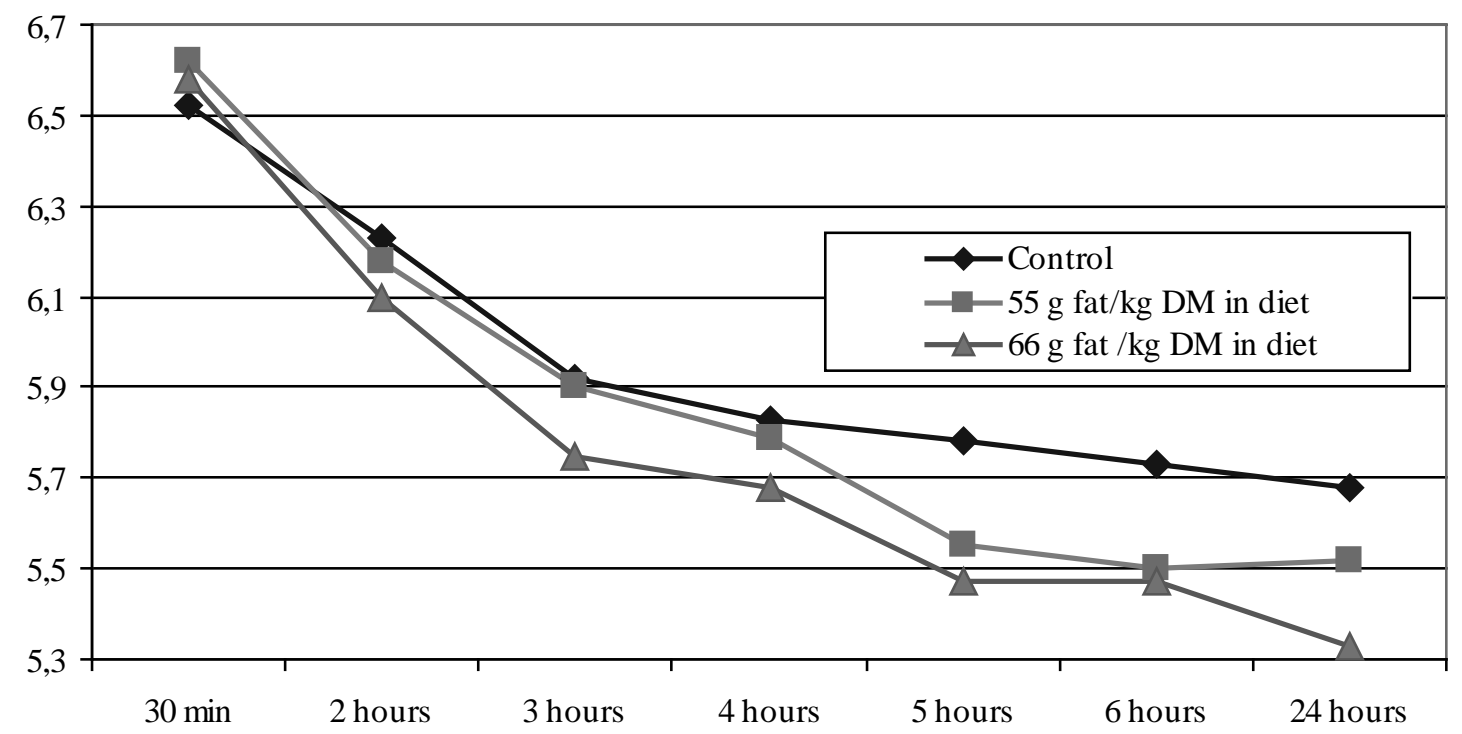

Fig. 1. The evolution of meat $\mathrm{pH}$ values in rabbits fed by vegetal fat enriched forage for 28 days vs control, during the first 24 hours from slaughter

concentration of vegetal fat in forage in the sequence of 5.72 (control) $\rightarrow 5.60$ (group A) $\rightarrow 5.53$ (group B). The maximum influences were found in the group fed $66 \mathrm{~g}$ fat / $\mathrm{kg}$ DM in the diet, due to the occurrence of a higher percentage of free fatty acids. Higher meat $p \mathrm{H}$ values were found in rabbits fed by animal or vegetal enriched diets, regardless of muscle mass that measured (Pla and Cervera, 1997). Vitamin E supplementation improve the evolution of the meat $p \mathrm{H}$ : Virag et al. (2012) found higher level of vitamin E compared to the lower level significantly increased loin $p \mathrm{H}(5.96$ and 5.90; $\mathrm{P}<0.05)$. Different muscular values reported Blasco and Piles (1990): there were some differences between 15-20 min and $24 \mathrm{~h}$ post slaughter meat $\mathrm{pH}$. Final $p \mathrm{Hs}$ were 5.71 and $5.66(L$. dorsi) and 5.82 and 5.77 (B. femoris): drop in $p \mathrm{H}$ was 1.00 and 1.05 (L. dorsi) or 0.77 and 0.83 (B. femoris). Strain and breed differences were also reported, due to a different metabolism (Blasco and Piles, 1990).

Meat composition of the two experimental groups vs. control is presented in Table 3.

The results presented in Table 4 revels a significant increase of the meat fat content in both, $A$ and B experimental groups. Dry matter of the samples was also significantly increased in experimental groups vs. control. Different factors were found to influence the meat composition: Prezuiso et al. (2008) reported that the housing system significantly affected the dry matter, protein and fat contents that were significantly higher in rabbit outdoor groups vs. indour groups. Fernández and Fraga (1996) concluded that dietary supplementation of linseed oil plus selenium in growing rabbits had a beneficial effect on the composition of the meat lipid fraction by increasing the concentration of unsaturated fatty acids and decreasing the concentration of saturated fatty acids and improving the growth performance. According to Petraacci and Cavani (2012), a higher fat content of the rabbit meat could be an alternative of the use of different fat sources (fat from plants or animals) for rabbit sausage manufacture. This should be avoided in order to preserve the current healthy image of rabbit meat, which is leaner in respect with other kinds of meat. On the other hand, fat composition can be also manipulated by dietary means as proven by many studies (Hernandez \& Gondret, 2006, cited by Petraacci and Cavani, 2012).

Results regarding the effect of fat enriched diets on the sensory traits of the meat are presented in Table 4. Significant differences between control and experimental treated groups were found for aroma intensity and quality and for juiciness, but there were not found significant differences between control and experimental treated groups for tenderness, taste intensity, taste quality and overall sensory quality.

\section{CONCLUSION}

Feeding the growing rabbits by different sunflower oil enriched diets could improve growth 
Tab. 3. The meat composition in rabbits fed for 28 days by different levels of vegetal oil enriched diets (determined on samples from the hind legs)

\begin{tabular}{ccccc}
\hline Item & $\begin{array}{c}\text { Control } \\
(\mathrm{n}=6)\end{array}$ & $\begin{array}{c}\text { Group A } \\
(55 \mathrm{~g} \text { fat/kg DM in diet, } \mathrm{n}=5)\end{array}$ & $\begin{array}{c}\text { Group B } \\
(66 \text { g fat/kg DM in diet, } \mathrm{n}=5)\end{array}$ & P value \\
\hline Fat & $1.43 \pm 0.22$ & $1.87 \pm 0.32$ & $2.89 \pm 0.83$ & 0.0321 \\
\hline Protein & $22.98 \pm 3.44$ & $21.65 \pm 3.05$ & $21.98 \pm 3.54$ & 0.0760 \\
\hline Dry matter & $24.21 \pm 2.12$ & $24.98 \pm 3.05$ & $25.15 \pm 3.55$ & 0.0454 \\
\hline Ash & $1.29 \pm 0.05$ & $1.18 \pm 0.31$ & $1.22 \pm 0.21$ & 0.0859 \\
\hline
\end{tabular}

Table 4. Sensory traits of the meat in rabbits fed by vegetal oil enriched diets for 28 days vs. a control fed by a standard diet

\begin{tabular}{lcccc}
\hline Item & $\begin{array}{c}\text { Control } \\
\text { (24 g/kg DM vegetal } \\
\text { oil in diet, n=6) }\end{array}$ & $\begin{array}{c}\text { Group A } \\
\text { (55 g fat/kg DM } \\
\text { in diet, n=5) }\end{array}$ & $\begin{array}{c}\text { Group B } \\
\text { (66 g fat/kg DM } \\
\text { in diet, n=5) }\end{array}$ & P \\
\hline Aroma intensity & 4.2 & 4.7 & 4.7 & 0.0210 \\
Aroma quality & 3.9 & 4.5 & 4.5 & 0.0492 \\
Tenderness & 4.4 & 4.6 & 4.5 & 0.0920 \\
Juiciness & 4.4 & 4.8 & 4.8 & 0.0093 \\
Taste intensity & 4.6 & 4.7 & 4.8 & 0.4904 \\
Taste quality & 4.6 & 4.6 & 4.7 & 0.0688 \\
Overall sensory quality & 4.5 & 4.6 & 4.7 & 0.0901 \\
\hline
\end{tabular}

rate, carcass traits and some meat sensory traits, due to an increase of carcass dissectible fat and an increase of meat fat content. These could be taken into account to obtain a rabbit meat according to consumer demands.

\section{REFERENCES}

1. AOAC Official methods of Analysis (1990). Meat and meat products. $39,15^{\text {th }}$ ed. Publications, Washington, DC, USA, 931-933.

2. Bălăceanu R, Cotor G, Cornilă N (2013). Physiological effects of vegetal fat enriched diets on the rabbit skeletal muscle: (i) composition and structure. Scientific works, C series, F.V.M. Bucharest, LIX (2), p. 28-33.

3. Bielanski P, D. Kowalska (2008). Use of linseed oil and antioxidant (vitamin E) in rabbit diets to imporve dietetic traits of rabbit meat. Proceeding of $9^{\text {th }}$ World Rabbit Congress, 319-1, 323.

4. Blasco, A, M. Piles (1998). Muscular $p \mathrm{H}$ of the rabbit. Ann. Zootech 39, 133-136

5. Blasco A., J. Ouyahoun (1993). Harmonization of criteria and terminology in rabbit meat research. Revised proposal. World Rabbit Science, 4 (2), 93-99.

6. Fernández, C., M. J. Fraga (1996). The effect of dietary fat inclusion on growth, carcass characteristics, and chemical composition of rabbits. J. anim. sci., vol. 74(9), 2,0882,094 .
7. Matics Zs., Zs. Gerencsér, A. Szabó, H. Fébel, M. Szin, I. Radnai, St. Szendrő (2012). Effect of supplementation of linseed oil, vitamin $\mathrm{E}$ and selenium in diet on meat quality of growing rabbit. Proceedings $10^{\text {th }}$ World Rabbit Congress, 967-971.

8. Pla, M., C. Cervera (1997). Carcass and meat quality of rabbits given diets having a high level of vegetable or animal fat. Animal Science. 65(2), 299-303.

9. Preziuso, G., A. Dalle Zotte, M. D'Agata, C. Russo and G. Paci (2008). Effect of outdoor rearing system, in floor cage, on meat quality of slow growing rabbits. Proceeding of $9^{\text {th }}$ World Rabbit Congress, 1,431-1,435.

10. Szendrő Zs., Gerencsér Zs., Szabó A., Fébel H., Szín M., Radnai I., Dalle Zotte A., Matics Zs. (2012). Effect of supplementation of linseed oil, vitamin E and selenium in diet for growing rabbits on productive and carcass traits. Proceedings $10^{\text {th }}$ World Rabbit Congress, 881-885.

11. Petracci M., C. Cavani (2012). Trend in rabbit meat slaughtering and meat processing. Proceedings $10^{\text {th }}$ World Rabbit Congress, 851- 858.

12. Saleh, A.A., T. Ebeid, Y. Z. Eid (2013). The Effect of Dietary Linseed Oil and Organic Selenium on Growth Performance and Muscle Fatty Acids in Growing Rabbits. Pakistan Veterinary Journal. 33 (4): 450-454.

13. Xiccato, G. (1999). Feeding and meat quality in rabbits: a review, World rabbit science, 7(2), 75-86. 